\title{
Inovasi Perencanaan Pembangunan Berbasis Ekowisata: Sebuah Kajian Pustaka Sistematis
}

\section{Ecotourism-based Development Planning Innovation: A Systematic Literature Review}

\author{
Ul Inati ${ }^{1 *} \&$ Salahudin ${ }^{1}$
}

\begin{abstract}
${ }^{1}$ Program Studi Ilmu Pemerintahan, Universitas Muhammadiyah Malang, Jalan Raya Tlogomas Nomor 246, Kota Malang, Indonesia; *Penulis korespondensi.e-mail: yannali184@gmail.com
\end{abstract}

(Diterima: 5 Juni 2021; Disetujui: 22 September 2021)

\begin{abstract}
Tourism is an economic activity or a series of coordinated activities aiming at meeting individual needs related to leisure and movement of people. Tourism sector is well known as the sector that has the largest contribution for foreign exchange in Indonesia. Development planning itself can be said as an alternative to the government in carrying out the task of realizing a change in certain areas to be able to catch up with other regions. The application of innovation aims to develop a renewal involving several stakeholders. Ecotourism is an innovation that can be applied in promoting development planning in a real context. The purpose of this research is to find out the scientific trend about development planning ecotourism by using bibliometric analysis through the VOSviewer application. This research uses qualitative research with a literature review approach. The results consist of mapping and clustering the results of previous research in the form of image visualization media with network and density mapping. Projections of development planning by creating ecotourism-based innovations have been carried out in various parts of the world. The existence of development and its linkage with the tourism sector makes a positive impact on people's lives, especially rural communities. Limitations of this study is that only correlations on the existence of development in the tourism sector are presented.
\end{abstract}

Keywords: bibliometric analysis, development planning, ecotourism, stakeholders

\begin{abstract}
ABSTRAK
Pariwisata adalah kegiatan ekonomi atau serangkaian kegiatan terkoordinasi yang ditujukan untuk memenuhi kebutuhan individu yang berkaitan dengan waktu luang dan pergerakan orang. Seperti yang diketahui, sektor pariwisata merupakan sektor yang memiliki kedudukan penyumbang devisa negara terbesar di Indonesia. Perencanaan pembangunan dapat dikatakan sebagai alternatif pemerintah dalam mengemban tugas untuk mewujudkan suatu perubahan pada wilayah-wilayah tertentu untuk dapat mengejar ketertinggalan dengan wilayah lain. Penerapan inovasi dalam konteks yang bertujuan untuk mengembangkan sebuah pembaharuan melibatkan beberapa pemangku kepentingan. Ekowisata adalah sebuah inovasi yang dapat diterapkan dalam mengedepankan perencanaan pembangunan dalam konteks yang nyata. Tujuan penelitian ini adalah untuk mengetahui trend keilmuan tentang development planning ecotourism dengan menggunakan analisis bibliometrik melalui aplikasi VOSviewer. Penelitian ini menggunakan jenis penelitian kualitatif dengan pendekatan literature review, dengan hasil terdiri dari pemetaan dan pengklasterisasian hasil penelitian terdahulu berbentuk media visualisasi gambar dengan pemetaan
\end{abstract}


network dan density. Proyeksi perencanaan pembangunan dengan menciptakan inovasi berbasis ekowisata sudah banyak dilakukan di berbagai penjuru dunia. Keterkaitan pembangunan dengan sektor pariwisata memiliki dampak positif bagi kehidupan masyarakat, khususnya masyarakat pedesaan. Keterbatasan penelitian ini yaitu peneliti hanya menyajikan korelasi tentang adanya pembangunan pada sektor pariwisata.

Kata kunci: analisis bibliometrik, ekowisata, pemangku kepentingan, perencanaan pembangunan

\section{PENDAHULUAN}

Sektor pariwisata merupakan sektor yang paling banyak diminati untuk menikmati keindahan alam yang dapat dijadikan sebagai alternatif untuk berlibur. Namun, dengan adanya pandemi Covid-19 mengakibatkan sektor pariwisata menjadi terhambat dalam proses pelaksanaannya untuk memperoleh pendapatan. Sehingga banyak masyarakat yang kehilangan pekerjaan terlebih lagi bagi masyarakat yang mengandalkan potensi pariwisata di dekat mereka tinggal. Sehingga pemerintah diharapkan lebih memperhatikan lagi bagaimana cara menyeimbangkan adanya permasalahan ini untuk tidak menjadi keterpurukan bagi masyarakat yang mata pencahariannya mengandalkan pariwisata. Mengingat pandemi semakin menyebar di berbagai penjuru wilayah negara termasuk Indonesia. Kegiatan pariwisata telah memberikan kontribusi yang nyata terhadap peningkatan simpanan tahunan anggota masyarakat tetapi keuntungan finansial ini tidak secara merata melampaui semua bidang pembangunan berbasis masyarakat yang berkelanjutan (Datta \& Banerji, 2015). Pariwisata memiliki tantangan dan peluang unik dalam hal adaptasi iklim (Pyke et al., 2018).

Perencanaan pembangunan merupakan suatu tindakan para pemangku kepentingan atau pemerintah dalam mengembangkan suatu potensi yang ada di wilayah baik di desa, daerah dan juga negara. Perencanaan dengan pendekatan partisipatif merupakan strategi pembangunan dan proses penentuan keputusan publik, hal ini sangat bergantung pada kesadaran masyarakat untuk mau melibatkan diri dalam proses pembangunan (Akbar et al., 2018). Dalam pengembangan suatu bidang, diperlukan adanya titik fokus dari adanya perencanaan pembangunan yang harus dilakukan demi terwujudnya suatu harapan yang nyata untuk menyelaraskan suatu indikasi rencana kinerja pemerintah. Perencanaan pembangunan sendiri dapat dikatakan sebagai alternatif pemerintah dalam mengemban tugas untuk mewujudkan suatu perubahan pada wilayah-wilayah tertentu untuk dapat mengejar ketertinggalan dengan wilayah lain. Perencanaan pembangunan ini pun tidak terlepas dari adanya konsep otonomi daerah. Salah satu aspek Implementasi Otonomi Daerah adalah pengelolaan keuangan daerah. Pengelolaan keuangan daerah merupakan suatu program daerah dalam bidang keuangan untuk mencapai tujuan dan sasaran tertentu serta mengemban misi mewujudkan suatu strategi melalui berbagai kegiatan (Mustanir et al., 2018).

Pada konteks perencanaan pembangunan suatu wilayah dengan memanfaatkan ruang terlebih lagi pemeliharaan alam, dapat dihadapkan pada perencanaan pembangunan dengan sektor pariwisata. Dimana pariwisata dapat merangsang ekonomi, mempromosikan pelestarian budaya, dan mendorong pelestarian lingkungan (Butler et al., 2017). Pariwisata adalah kegiatan ekonomi atau serangkaian kegiatan terkoordinasi yang ditujukan untuk memenuhi kebutuhan individu yang berkaitan dengan waktu luang dan pergerakan orang. Pariwisata memiliki potensi besar dan memainkan peran penting dalam memenuhi tujuan utama yang terkait dengan lapangan kerja, pembangunan ekonomi dan sosial yang berkelanjutan (Kuqi, 2018). Sektor pariwisata merupakan sektor yang memiliki kedudukan penyumbang devisa negara terbesar di Indonesia. Hal ini dibuktikan dengan adanya 
data dari Badan Pusat Statistik (BPS) yang menunjukkan setiap tahun (2016 hingga 2018) mengalami kenaikan devisa yakni pada tahun 2016 terdapat 11,206 U\$; 2017 terdapat 13,139 U\$; 2018 terdapat 16,426 U\$. Dalam hal ini, perencanaan pembangunan juga dapat dikaitkan dengan pembangunan pariwisata berkelanjutan sebagai output dalam konteks perubahan suatu wilayah. Untuk mencapai pembangunan pariwisata berkelanjutan yang sukses, intervensi harus memberi kemampuan kepada kelompok yang mendukung pariwisata untuk memimpin inisiatif, merayu yang enggan, memberi energi kepada mereka yang ingin bermigrasi dan bernegosiasi dengan agen wisata eksternal untuk mencapai pembangunan pariwisata yang lebih adil dimana penduduk setempat berpartisipasi aktif (Sarr et al., 2020).

Dalam konseptualisasi perencanaan pembangunan melalui sektor pariwisata, pemerintah lebih mengedepankan pada lingkup wilayah perdesaan, dikarenakan banyak masyarakat perdesaan yang lebih menjaga keanekaragaman hayati atau menjaga potensi wilayah daerah. Sehingga masyarakat perdesaan lebih memiliki peluang dalam keterlibatan dengan adanya pembangunan ini. Hal ini juga dapat memberikan wadah bagi pemangku kepentingan dalam meningkatkan strategi agar dengan mudah memvisualisasikan atau mengidentifikasi batasan dan menetapkan prioritas pembangunan dalam proses peningkatan langkah demi langkah, menuju pengelolaan dan pengembangan destinasi wisata yang berkelanjutan melalui ekowisata (Iliopoulou-Georgudaki et al., 2016).

Mendalami konteks perencanaan pembangunan dalam hal kesuksesan sebuah rencana tidak terlepas dari adanya inovasi yang dikembangkan untuk menyelaraskan adanya pembangunan. Salah satu inovasi yang dapat dikembangkan dalam konteks perencanaan pembangunan melalui sektor pariwisata adalah pembangunan pariwisata berbasis ekowisata sebagai pembaharuan pemanfaatan wilayah terbuka dan juga sebagai penghasilan suatu daerah dan masyarakatnya. Ekowisata perdesaan adalah jenis pariwisata baru yang diproduksi bagi orang-orang untuk menikmati pemandangan perdesaan. Lalu untuk memastikan pembangunan berkelanjutan dari ekowisata perdesaan, perlu dilakukan analisis perencanaan dalam banyak aspek (Shang et al., 2020). Ekowisata juga dapat dikatakan sebagai strategi yang efektif untuk mengurangi permasalahan pada keterbengkalaian terhadap suatu lahan dengan memperkenalkan bentuk kegiatan ekonomi yang bertanggung jawab dalam membangun keterkaitan antara konservasi dan pemberdayaan sosial (Pujar \& Mishra, 2020). Keterlibatan pemangku kepentingan atau pemerintah berperan sebagai pencetus adanya sebuah konsep pembangunan, masyarakat sebagai aspek utama dalam partisipasi dari adanya perencanaan pembangunan melalui inovasi yang diciptakan. Selain menciptakan lumbung pendapatan dan menstabilkan perekonomian, ekowisata juga dapat berperan dalam mengelola alam menjadi lahan tidak kosong.

Terlebih lagi Indonesia memiliki potensi alam yang mendukung untuk adanya pengembangan sektor pariwisata. Perencanaan tata ruang ekowisata membutuhkan keseimbangan antara pembangunan dan konservasi, penataan ruang berdasarkan tema dan mempertimbangkan kehidupan penduduk lokal di luar penataan ruang berdasarkan data fisik (Lee et al., 2017). Dengan adanya ketertarikan yang meningkat pada ekowisata dan jasa ekosistem yang disediakan oleh lanskap, membuat layanan tersebut semakin diperlukan dalam proses perencanaan kota (Guerrero et al., 2020). Ekowisata yang menekankan pelestarian alam sekaligus melakukan kegiatan wisata yang dimaksudkan untuk berdampak rendah pada kesejahteraan penduduk setempat telah berlangsung di sana selama beberapa dekade (Ching et al., 2020). Sistem ekowisata yang didasarkan pada habitat satwa liar dalam sistem ekologi dianggap sebagai sistem sosial-ekologis yang memiliki hubungan umpan balik dengan sistem sosial (Choi et al., 2017).

Dalam konteks pengembangan wisata berbasis ekowisata sendiri perlu adanya 
pengembangan aglomerasi diperkuat sebagai dasar pengelolaan lingkungan untuk pembangunan berkelanjutan di wilayah tersebut. Selain itu, dalam konteks wilayah kepemilikan lokasi diperlukan pengetatan batas atas kapasitas, mempertahankan garis bawah ekologis, bersikeras pada pemanfaatan lahan secara intensif, mengoptimalkan tata ruang "produksi, kehidupan dan ekologi", menyesuaikan struktur industri, dan mengembangkan ekowisata akan menjadi tindakan yang diperlukan. Terdapat empat jenis sistem ekowisata yang diklasifikasikan sebagai berikut: prasarana rendah dan prasarana penduduk, prasarana tinggi dan prasarana penduduk, prasarana tinggi dan prakarsa pemerintah, serta prasarana rendah dan prakarsa pemerintah (Choi et al., 2017). Sistem indeks pembangunan berkelanjutan dan model evaluasi pariwisata ekologi sangat penting dibangun untuk mengatur pembangunan kawasan wisata ekologi, mendorong pemanfaatan sumber daya pariwisata ekologi secara berkelanjutan dan memandu pembangunan ekowisata yang sehat (Mei, 2016). Kekuatan dalam mengembangkan ekowisata di suatu wilayah meliputi empat hal yang menjadi titik fokus utama dalam melakukan rencana pembangunan berbasis wisata alam yakni Kebijakan, Tanggung Jawab, Kelembagaan dan Partisipasi Warga (MestanzaRamón et al., 2020).

Dalam proses pengenalan ekowisata sendiri diperlukan informasi yang benar tentang sumber daya alam negara tersebut untuk menjadi turis lokal, daya tarik tidak hanya untuk wisatawan tetapi juga untuk orang asing (Kuqi, 2018). Perencanaan dan pengembangan ekowisata dapat secara praktis didukung oleh perangkat geo-informasi yang dikombinasikan dengan prosedur analisis keputusan multikriteria yang tepat berdasarkan keputusan yang lebih baik dapat dibuat (Wong \& Fung, 2016). Perencanaan yang tepat di bidang pengembangan ekowisata yang berkelanjutan dapat meminimalkan dampak negatif lingkungan dan memperbaiki kondisi sumber daya alam melalui investasi di bidang konservasi dan kehutanan (Yekani Motlag et al., 2020). Tujuan dari adanya penulisan artikel ini adalah untuk mengetahui tren keilmuan tentang Development Planning Ecotourism dengan menggunakan analisis bibliometrik melalui aplikasi VOSviewer. Selain itu, pentingnya penelitian ini dilakukan karena masih belum banyak dilakukan penelitian mengenai perencanaan pembangunan berbasis ekowisata dengan menggunakan metode analisis bibliometrik.

\section{METODOLOGI}

Penelitian ini menggunakan jenis penelitian kualitatif dengan pendekatan studi literatur, dimana data-data utama diperoleh dari jurnal-jurnal bereputasi internasional. Selain itu, artikel review dalam kajian ini diarahkan pada konseptualisasi kajian Ekowisata yang akan dijelaskan melalui pertanyaan-pertanyaan berikut, yakni: (1) Bagaimana hubungan klasterisasi tema dan kajian perencanaan pembangunan melalui Ekowisata? (2) Apa saja tema dominan dalam kajian perencanaan pembangunan melalui Ekowisata? (3) Apa saja topik yang berkaitan dengan kajian perencanaan pembangunan melalui Ecotourism? (4) Jenis pemetaan apa yang digunakan dalam studi Ecotourism? (5) Konsep apa yang digunakan dalam kajian perencanaan pembangunan melalui Ecotourism?. Pertanyaan-pertanyaan tersebut dijelaskan berdasarkan topik kajian, kerangka kerja, dan temuan penelitian sebelumnya yang terindeks dalam database Scopus. Artikel yang di review dalam penelitian ini melalui tahapan (1) pencarian artikel; (2) pemetaan topik. 


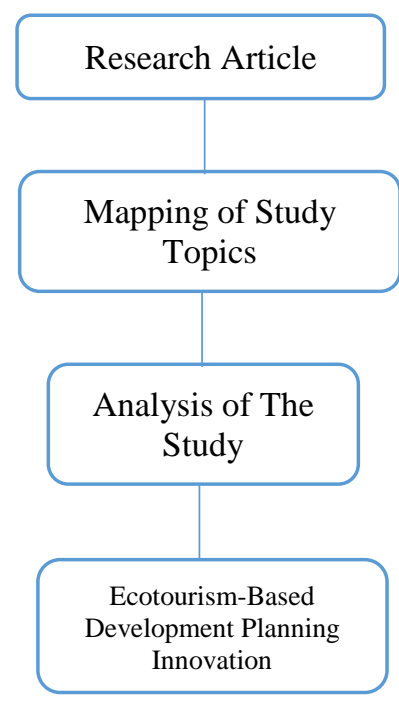

Gambar 1. Proses review artikel

Artikel ini dicari melalui beberapa tahap. Tahap pertama identifikasi artikel, artikelartikel yang digunakan diambil dari publikasi berbagai penerbit dengan menggunakan database Scopus. Langkah selanjutnya, peneliti melakukan pencarian menggunakan kata kunci "Development Planning dan Ecotourism" diambil dari berbagai tahun, sehingga peneliti harus mengklasterisasikan artikel berdasarkan ketetapan tahun terakhir yakni 10 tahun terakhir yakni dalam rentan waktu 2011 sampai 2021. Pencarian tersebut mendapatkan tampilan sebanyak 311 artikel yang bersangkutan dengan kata kunci dari topik penelitian yang diangkat. Angka tersebut didapat dari jumlah file berbentuk (ris) yang di export ke dalam software mendeley.

\section{HASIL DAN PEMBAHASAN}

\section{Keterkaitan dan Pengelompokan Tema} Kajian tentang Perencanaan Pembangunan berbasis Ekowisata (Ecotourism)

Pada bagian ini, dilakukan analisis bibliometrik dengan membuat visualisasi network dan density menggunakan aplikasi VOSviewer untuk mengetahui jaringan bibliometrik yang terdapat diantara artikelartikel yang diunduh pada data Scopus. Jaringan bibliometrik sendiri terdapat dua karakteristik yakni node dan edge. Node direpresentasikan dengan simbol lingkaran yang terdiri dari publikasi; jurnal; peneliti; dan kata kunci. Sedangkan edge mengindikasikan adanya hubungan antara node, tetapi juga mengindikasikan adanya hubungan tersebut direpresentasikan dengan jarak, semakin dekat jarak antar node maka semakin tinggi hubungan diantara node tersebut. Berikut hasil gambar visualisasi network dan density berdasarkan keterkaitan dan pengelompokan kata kunci.

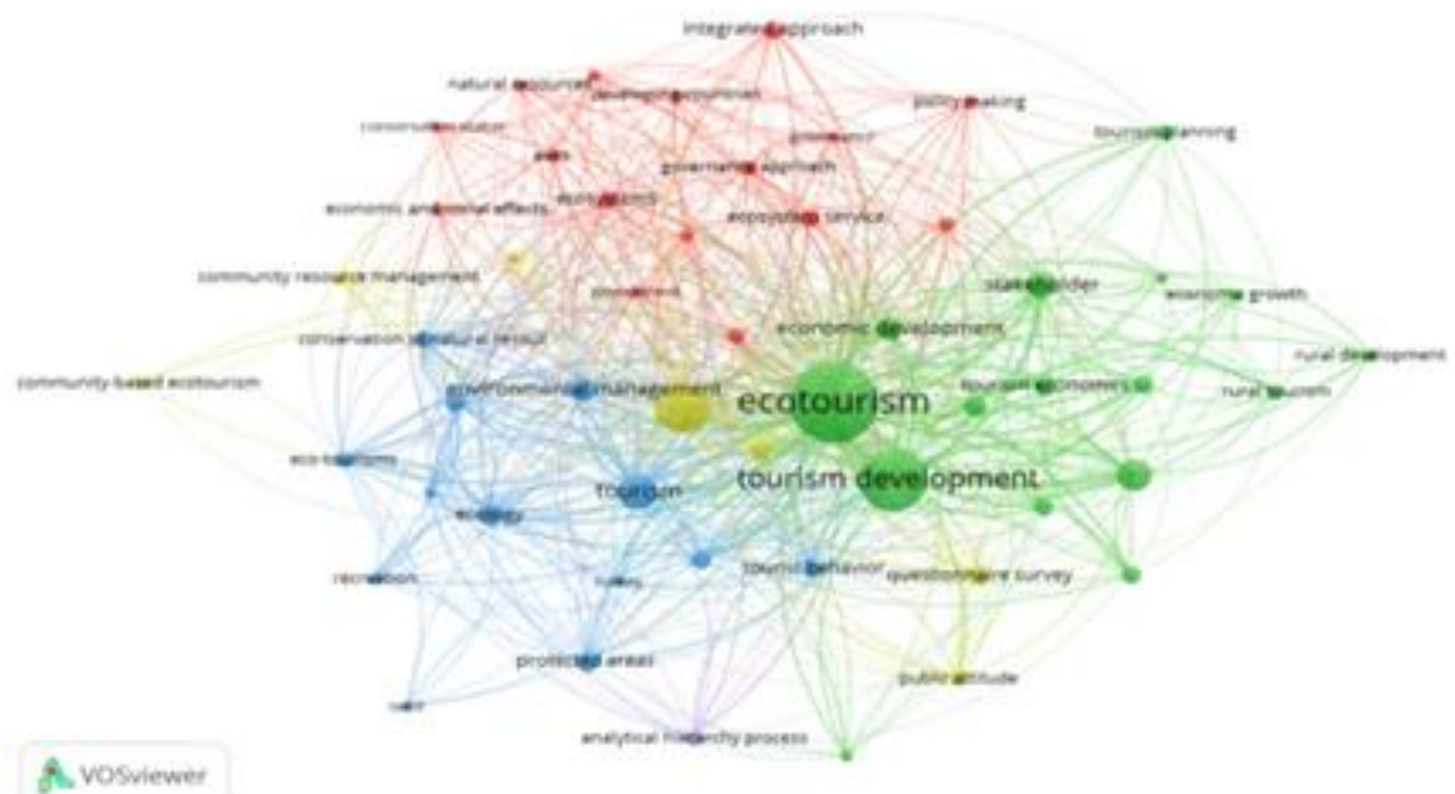

Gambar 2. Visualisasi network pemetaan dan pengklasterisasian dari 155 artikel yang telah teridentifikasi 
Pada visualisasi network yang ditampilkan pada Gambar 2, setiap lingkaran mewakili sebuah kata kunci yang dimana diambil dari judul dan abstrak artikel. Ukuran lingkaran besar dan kecil mengindikasikan jumlah publikasi yang memiliki relasi dengan kata kunci tersebut, lingkaran besar menunjukkan bahwa kata kunci tersebut merupakan inti dari data yang diperoleh berdasarkan tema riset yang diambil, baik abstrak maupun dalam jurnal.

Berdasarkan hasil klasterisasi artikel pada gambar di atas, menunjukkan bahwa dari 311 jurnal yang teridentifikasi melalui data ris hanya terdapat 155 artikel yang sesuai berdasarkan kata kunci yang sesuai dengan karakteristik judul artikel. Masing-masing klaster memiliki warna yang berbeda-beda yang digunakan untuk melihat daftar konsep yang menonjol dari setiap klaster. Berikut visualisasi kata kunci yang terdapat di dalam masingmasing klaster secara rinci pada Tabel 1.

Tabel 1. Tema Klaster penelitian mengenai Development Planning dan Ecotourism

\begin{tabular}{|c|c|c|}
\hline Klaster & Nama Konsep & Total \\
\hline $\begin{array}{c}\text { Klaster } \\
1\end{array}$ & $\begin{array}{lr}\text { aves, coastal } & \text { zone } \\
\text { management, } & \\
\text { conservation } & \text { status, } \\
\text { developing } & \text { countries, } \\
\text { developing } & \text { world, } \\
\text { economic and } & \text { social } \\
\text { effect, ecosystem } & \text { service, } \\
\text { ecosystems, } & \text { governance, } \\
\text { governance } & \text { approach, } \\
\text { government, } & \text { integrated } \\
\text { approach, } & \text { landscape } \\
\text { planning, } & \text { natural } \\
\text { resource. } & \end{array}$ & 16 \\
\hline $\begin{array}{c}\text { Klaster } \\
2\end{array}$ & 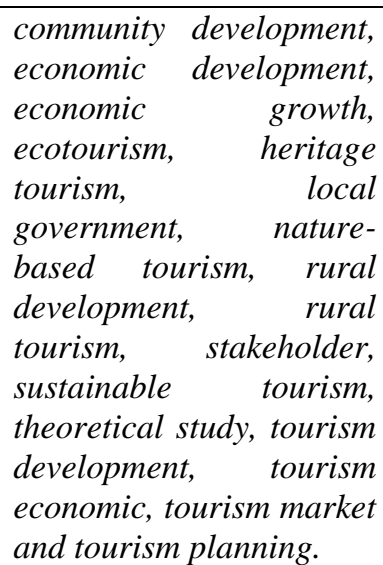 & 16 \\
\hline Klaster & conservation of natural & 13 \\
\hline
\end{tabular}

\begin{tabular}{|c|c|c|}
\hline Klaster & Nama Konsep & Total \\
\hline 3 & $\begin{array}{lr}\text { resources, } & \text { eco-tourism, } \\
\text { ecology, } & \text { environmental } \\
\text { management, } & \text { human, } \\
\text { natural } & \text { resource, } \\
\text { protected } & \text { areas, } \\
\text { recreation, swot, tourism, } & \text { tourist behavior, turkey. } \\
\end{array}$ & \\
\hline $\begin{array}{c}\text { Klaster } \\
4\end{array}$ & 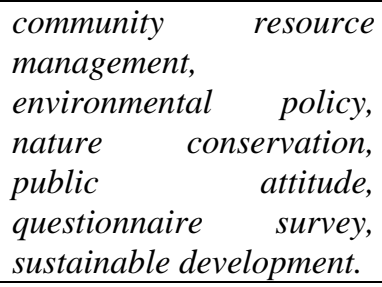 & 7 \\
\hline $\begin{array}{c}\text { Klaster } \\
5\end{array}$ & $\begin{array}{l}\text { analytical } \\
\text { process }\end{array}$ & 1 \\
\hline
\end{tabular}

Setelah dilakukan identifikasi pemetaan dan pengklasteran kata kunci sesuai dengan riset Development Planning dan Ecotourism, maka tahap selanjutnya dilakukan pemetaan artikel sesuai tahun terbit. Data yang didapatkan dari hasil visualisasi Network, menggunakan VOSviewer dapat digunakan untuk mengidentifikasi bagaimana tren penelitian yang dilakukan oleh peneliti sebelumnya mengenai Development Planning dan Ecotourism setiap tahunnya. Salah satu kata kunci yang membahas tentang perencanaan pembangunan berbasis Ekowisata adalah penelitian yang dilakukan oleh (Arkema et al., 2021) menyebutkan bahwa keputusan pembangunan dan konservasi, seperti tempat berinvestasi dalam infrastruktur untuk akses dan akomodasi pengunjung, penentuan lokasi kawasan lindung laut baru, dan pengelolaan kawasan lindung yang telah ditetapkan. Kebijakan dalam menginformasikan kinerja atau hasil sangat dibutuhkan sebagai bentuk nyata dari adanya relevansi pemanfaatan ekowisata sebagai pendukung untuk mengedepankan pembangunan. Penelitian lain yang dilakukan oleh (Gohar \& Mathias Kondolf, 2020) menyebutkan bahwa ekowisata adalah bagian yang berkembang dari industri pariwisata. Namun, tidak ada kriteria yang disepakati tentang apa yang merupakan ekowisata, sehingga industri saat ini mengidentifikasi dirinya sendiri, dengan ekologe hanya menyatakan diri mereka demikian, 
pendirian ekowisata yang diidentifikasi sendiri tidak berbeda secara signifikan dari resor pariwisata konvensional dalam hal tekanan pada sumber daya lingkungan.

Selain itu berdasarkan penelitian yang dilakukan oleh (Shang et al., 2020) yang berjudul "Rural Ecotourism Planning and Design Based on SWOT Analysis" mengemukakan bahwa pengembangan ekowisata perdesaan Tianjin memiliki empat keunggulan, yaitu transportasi yang nyaman, sumber daya air yang kaya, sumber daya hewani dan tumbuhan yang kaya, dan sumber daya ekowisata yang kaya; tiga kelemahan, yaitu konten yang homogen, tema yang tidak jelas, dan kualitas staf yang rendah; tiga peluang, yaitu dukungan pemerintah, kombinasi budaya lokal yang efektif dengan kegiatan pariwisata dan peningkatan permintaan akan pariwisata; dan dua ancaman, yaitu persaingan yang ketat di antara teman sebaya dan permintaan wisatawan yang beragam. Dengan demikian dapat dikatakan bahwa karakteristik perencanaan pembangunan diperlukan keunggulan dalam konteks kesuksesan sebuah perencanaan pembangunan yang akan dilakukan melalui ekowisata sebagai jembatan dalam adanya perubahan sebuah wilayah.

Selain itu, juga diperlukan adanya posisi komunitas di dalam perencanaan sebagai media utama sebuah inovasi perencanaan pembangunan melalui ekowisata. Serta, temuan yang dikemukakan oleh peneliti terdahulu yang membahas tentang perencanaan pembangunan berbasis ekowisata dapat diadopsi dalam mengembangkan perencanaan pembangunan melalui ekowisata di Indonesia. Selain itu pengembangan ekowisata di tingkat negara bagian yang akan berkontribusi pada pertumbuhan PDB negara. Ide dari adanya pengembangan ekowisata tersebut dapat memberikan suatu hasil yang menggabungkan kebijakan dari pihak pemerintah dan strategi yang digunakan dalam pengembangannya di tingkat organisasi, perencanaan tata ruang, tingkat masyarakat lokal yang juga akan menguntungkan masyarakat lokal dengan menciptakan lapangan kerja serta melestarikan kekayaan keanekaragaman hayati (Baruah, 2020). Dengan adanya konsep perencanaan pembangunan melalui ekowisata ini mengedepankan konsep yang menghargai sumber daya alam dan budaya masyarakat tertentu dan mendorong partisipasi anggotanya dalam proses penciptaan produk wisata. Artikel ini beroperasi pada tahap perencanaan dan bertujuan untuk memberikan wawasan tentang proses membangun dasar untuk pariwisata berbasis masyarakat (Đukić \& Volić, 2017).

Peranan pemerintah dalam konsekuensi berjalannya inovasi yang dirancang untuk membuahkan sebuah perubahan yang signifikan dalam menggenjot perekonomian melalui sektor pariwisata berbasis ekowisata, seperti halnya penelitian yang dilakukan oleh (Ayorekire et al., 2019) dengan judul "Regional tourism in Inter-Governmental Authority on Development: A comparative policy and institutional best practice approach" menyatakan sebagian besar REC memiliki struktur kelembagaan yang ramping dengan kebijakan pariwisata regional yang kuat dan kerangka kerja perencanaan kelembagaan yang telah membantu memperkuat daya saing global mereka. Meskipun memiliki rencana induk pariwisata berkelanjutan, wilayah ini tetap kekurangan kerangka kebijakan dan kelembagaan, sebuah celah yang berusaha diisi oleh makalah ini berdasarkan analisis kerangka komparatif dari REC lainnya. REC atau komunitas ekonomi regional ini diperlukan peran pemerintah dalam merealisasikan perencanaan pembangunan yang akan dilakukan. Pemerintah berperan sebagai pihak tertinggi dalam adanya pelaksanaan pembangunan yang akan dilakukan, karena pemerintah sebagai pemegang atau pembuat kebijakan inovasi perencanaan pembangunan terlebih lagi melibatkan suatu wilayah. Kondisi budaya manusia dan kondisi alam adalah elemen inti dari sumber daya ekowisata perdesaan, dan pentingnya pemandangan alam dan benda-benda budaya yang paling menonjol (Xiang et al., 2020).

Pada klaster 2, kata kunci paling dominan adalah kata kunci Ecotourism dimana 
penelitian yang dilakukan oleh (Walter, 2020) yang berjudul "Community-based ecotourism projects as living museums" menyatakan bahwa Community Based Ecotourism (CBE) mempromosikan pelestarian lingkungan alam, mata pencaharian, dan budaya lokal. Seperti museum hidup, CBE adalah situs yang kaya akan pembelajaran pengunjung berdasarkan pengalaman, tetapi tanpa desain yang sengaja dikurasi dari karakteristik pembelajaran museum. Selanjutnya kata kunci pada klaster 2 tourism development yang dikemukakan oleh (Duan et al., 2019) dengan judul "Land use and land cover change in the Kailash Sacred Landscape of China" menyebutkan bahwa Penggunaan lahan dan perubahan tutupan lahan (LUCC) merupakan pendorong penting dari fungsi dan layanan ekosistem. Dengan demikian, analisis LUCC dapat menjadi dasar untuk perencanaan lanskap, konservasi dan pengelolaan. Ini terutama berlaku untuk lanskap alpen, yang lebih rentan terhadap perubahan iklim dan aktivitas manusia. Hal ini menunjukkan bahwa penggunaan lahan menjadi faktor yang penting pada saat inovasi ekowisata dilaksanakan sebagaimana mestinya. Ketersediaan lahan menjadi penentu utama dalam merealisasikan pembangunan yang direncanakan oleh beberapa stakeholder yang terlibat.

Kemudian penelitian yang dilakukan oleh (Salemi et al., 2019) dengan judul artikel "Conceptual framework for evaluation of ecotourism carrying capacity for sustainable development of Karkheh protected area, Iran" menyatakan bahwa pemeliharaan ekosistem alami dan perawatan terhadap masuknya manusia tidak perlu memerlukan model yang modern dan efisien seperti model daya dukung untuk mengoptimalkan pengelolaan dan pengembangan ekowisata di kawasan tersebut. Model tersebut adalah salah satu alat kunci untuk konservasi dan keberlanjutan kawasan ini. Selain itu, terdapat penelitian yang dilakukan oleh (Zhou et al., 2019) dengan judul artikel "A study on the influence of ecotourism promotion method and brand attitude on consumers' willingness to buy" mengemukakan bahwa dalam proses pembangunan berkelanjutan, menciptakan situasi win-win antara pengembangan pariwisata dan kepentingan penduduk, mengurangi dampak terhadap ekologi atau humaniora, dan memperluas kedalaman dan luasnya pasar ekowisata telah menjadi tujuan bisnis eko yang berkelanjutan industri pariwisata. Untuk mencapai tujuan bisnis perusahaan dengan lebih baik, perusahaan menggunakan berbagai metode efektif untuk mempromosikan kepada konsumen agar lebih memahami produk dan lebih memperhatikan merek perusahaan, sehingga pada akhirnya meningkatkan kemauan konsumen untuk membeli. Oleh karena itu, berdasarkan teori tersebut, penelitian ini menerapkan pasar ekowisata untuk menguji pengaruh metode promosi dan sikap merek terhadap kesediaan konsumen untuk membeli.

Kemudian pada klaster 3 kata kunci dominan adalah tourism, dimana terdapat penelitian yang dilakukan oleh (Shang et al., 2020) dengan judul "Rural ecotourism planning and design based on SWOT analysis" mengemukakan bahwa ekowisata perdesaan adalah jenis pariwisata baru yang diproduksi bagi orang-orang untuk menikmati pemandangan perdesaan. Untuk memastikan pembangunan berkelanjutan dari ekowisata perdesaan, perlu dilakukan analisis perencanaan dalam banyak aspek. Selain itu keberadaan wisatawan menjadi penentu dari adanya keunggulan suatu potensi yang dimiliki oleh suatu wilayah tersebut.

Klaster 4 sendiri didominasi oleh kata kunci sustainable development yang dikemukakan oleh (Elbarmelgy et al., 2019) dengan judul "Community-based ecotourism planning in Egypt, a case study: Evaluation of dahshur initiative" menyebutkan bahwa Ekowisata Berbasis Komunitas (CBE) telah menjadi pendekatan terbaru dalam proses perencanaan pembangunan pariwisata, muncul untuk mendukung keterlibatan masyarakat, untuk meningkatkan taraf hidup masyarakat dan melindungi sumber daya alam. Sehingga dengan adanya komunitas tersebut akan dapat menjadikan sebuah pembaharuan yang relevan. 
Adapun langkah yang dapat ditempuh untuk melakukan sebuah langkah pengembangan CBE itu sendiri adalah (1) Modernisasi dan reorganisasi struktur administrasi publik, dengan fokus pada pemanfaatan sumber daya secara optimal, daripada melekat pada tradisi; (2) Membentuk kelompok mitra yang berbeda;

(3) Penguatan basis pengetahuan keputusan tentang pengelolaan pariwisata berkelanjutan; dan (4) Meningkatkan perencanaan sadar, berdasarkan masuknya kelompok kepentingan yang berbeda dan prognosis jangka panjang dalam pengambilan keputusan lokal, meminimalkan beban lingkungan pariwisata (Lakner et al., 2018).

Selain itu, inovasi Community Based Ecotourism sendiri akan menimbulkan sebuah dampak yang baik bagi suatu lingkup daerah terlebih lagi pada wilayah Indonesia yang memiliki banyak tempat wisata alam. Sehingga pemanfaatan dari wisata alam tersebut dapat menjadikan suatu wilayah menambah pendapatan daerah terlebih lagi di masa pandemi yang seperti sekarang. Penerapan konsep CBE sendiri di Indonesia telah dilakukan di beberapa tempat, salah satunya ada pada wilayah Gili Labak, Jawa Timur, namun pelaksanaan CBE sendiri dapat dikatakan belum berhasil. Hal ini dibuktikan dari penelitian yang dilakukan oleh (Rahardjanto et al., 2019) yang menyatakan bahwa tim pengelola Gili Labak belum serius memikirkan prinsip bahwa partisipasi masyarakat harus menjadi kekuatan dalam pengelolaan ekowisata. Jika partisipasi masyarakat diabaikan, pengembangan ekowisata akan terhambat atau bahkan terhenti. Perbaikan di segala bidang harus dilakukan dengan baik sehingga memberikan dampak positif bagi masyarakat setempat dan berkelanjutan. Hal ini memerlukan komunikasi antar pemangku kepentingan dan aktor-aktor yang terlibat di dalam pengembangan ekowisata. Strategi komunikasi yang beragam dapat membantu dengan cepat menerjemahkan sains yang dipublikasikan ke dalam tindakan konservasi baru dengan memberikan bukti yang tepat kepada pemangku kepentingan dengan cara yang benar untuk menginformasikan praktik khusus (Noble \& Fulton, 2020).

Klaster 5 dengan satu kata kunci analytical hierarchy process yang dikemukakan oleh (Jiang et al., 2019) dengan judul "Interpretation of value advantage and sustainable tourism development for Railway Heritage in China based on the analytic hierarchy process" menyebutkan bahwa rekomendasi untuk pengembangan pariwisata Kesehatan Reproduksi diajukan berdasarkan keunggulan nilai ini. Analisis keuntungan nilai di antara sumber daya serupa dalam suasana kompetitif memperkuat keputusan konservasi dan pembangunan. Dengan demikian, pembangunan pariwisata kesehatan reproduksi yang seimbang dan berkelanjutan dapat tercapai. Dengan adanya pengembangan pariwisata kesehatan reproduksi tersebut memberikan gambaran kepada pemangku kepentingan bahwa proses hierarki yang dapat dilakukan juga harus mengedepankan kegiatan yang dapat memberikan keunggulan atau nilai yang baik terhadap adanya proses pengembangan inovasi.

Selain itu penelitian lain yang dilakukan oleh (Zhang \& Sui, 2020) menyatakan bahwa konseptualisasi dari adanya pembangunan berkelanjutan melalui pariwisata terdapat beberapa aspek temuan yang berimplikasi pada konteks bidang yang bersangkutan yakni: 1) Jejak ekologis perjalanan penduduk (EF) dan tapak ekologi areal kurang dari kapasitas ekologi, total wilayah EF baik yang terbentuk juga dalam lingkup kapasitas ekologi, jelas socio Pembangunan ekonomi di kawasan wisata pembangunan berkelanjutan negara; 2) Kegiatan pariwisata dalam jejak ekologi pariwisata dari masing-masing karakterisasi subsistem, dampak maksimum pada lalu lintas dan belanja pada lingkungan ekologis; 3) Kegiatan pariwisata dan produksi sehari-hari serta kehidupan penduduk lokal terhadap dampak lingkungan mekanisme memiliki perbedaan yang signifikan. Dengan memperhatikan suatu sub-sistem yang dimana dapat menjadikan suatu pembangunan dapat terealisasi, maka sangat diperlukan apabila 
konteks perencanaan pembangunan dapat menjadi suatu kinerja khusus untuk menggenjot perekonomian melalui inovasi Community Based Tourism.

\section{Tema Dominan dalam Studi Collaborative Governance Green Open Space}

Selanjutnya dilakukan tahapan visualisasi density. Hasil tahapan ini dapat diidentifikasikan berdasarkan warna kepadatan pada visualisasi tersebut. Dimana warna kuning pada visualisasi data density di bawah yakni kata kunci ecotourism; tourism development; environmental management adalah yang paling dominan. Berikut adalah visualisasi data density mengenai Development Planning dan Ecotourism.

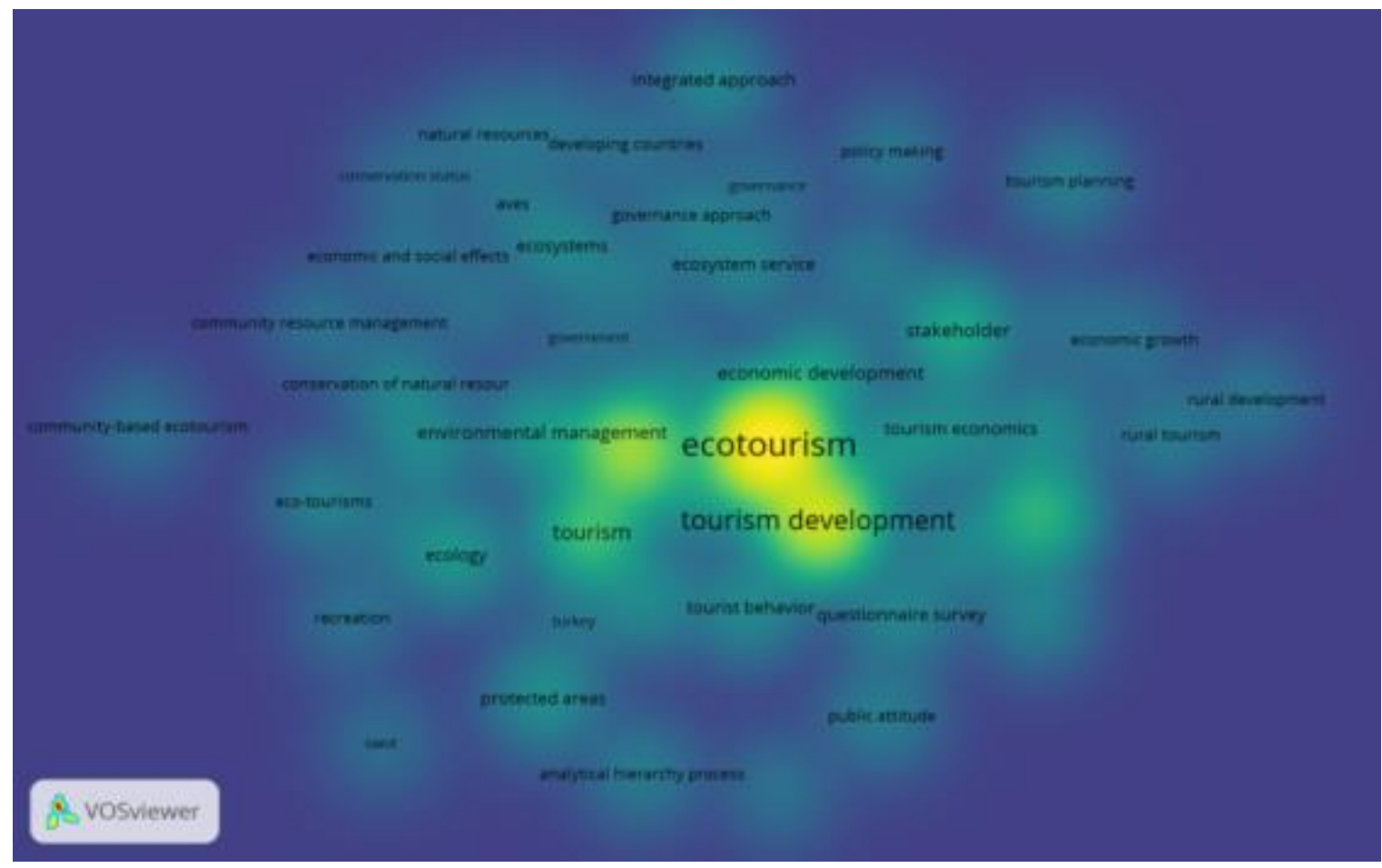

Gambar 3. Visualisasi Density Pemetaan dan Pengklasteran berdasarkan kata kunci dominan

Dalam kajian ini penerapan ekowisata dalam perencanaan pembangunan dibutuhkan tourism development atau pengembangan pariwisata sebagai bentuk konsekuensi dari adanya pengembangan aspek ekowisata yang akan diterapkan. Dikarenakan aspek tersebut memiliki peran penting dalam merealisasikan sebuah inovasi yang dapat disebut dengan Community Based Ecotourism. Selain itu, juga perlu adanya pengembangan lingkungan atau environmental development sebagai bentuk langkah dasar untuk merealisasikan adanya ekowisata. Jelas bahwa ekowisata adalah objek wisata yang mengedepankan ekosistem alam sebagai media utamanya. Potensi daya tarik wisata berbasis mata pencaharian dan berbasis alam serta peluang pasar wisata. Namun, ada faktor resistensi yang perlu diatasi, terutama dalam mencegah degradasi hutan lebih lanjut, meningkatkan akses ke atraksi wisata, dan memberdayakan masyarakat (Yuwono et al., 2021). Selain itu, pengembangan potensi penggunaan lahan khususnya kawasan terbangun memperhatikan masyarakat sekitar untuk menikmati lingkungan yang segar dan nyaman (Nor et al., 2018). Sehingga dengan adanya pengembangan ekowisata ini, mampu menjadikan lahan alami dan lahan alami buatan sebagai sebuah peluang destinasi di suatu daerah.

\section{Author Dominan dalam Studi Collaborative Governance Green Open Space}

Setelah melakukan 2 visualisasi yang meliputi network dan density terkait kata kunci, 
selanjutnya dilakukan visualisasi network dan

tentang Development Planning dan Ecotourism. density terkait penulis atau author dalam riset

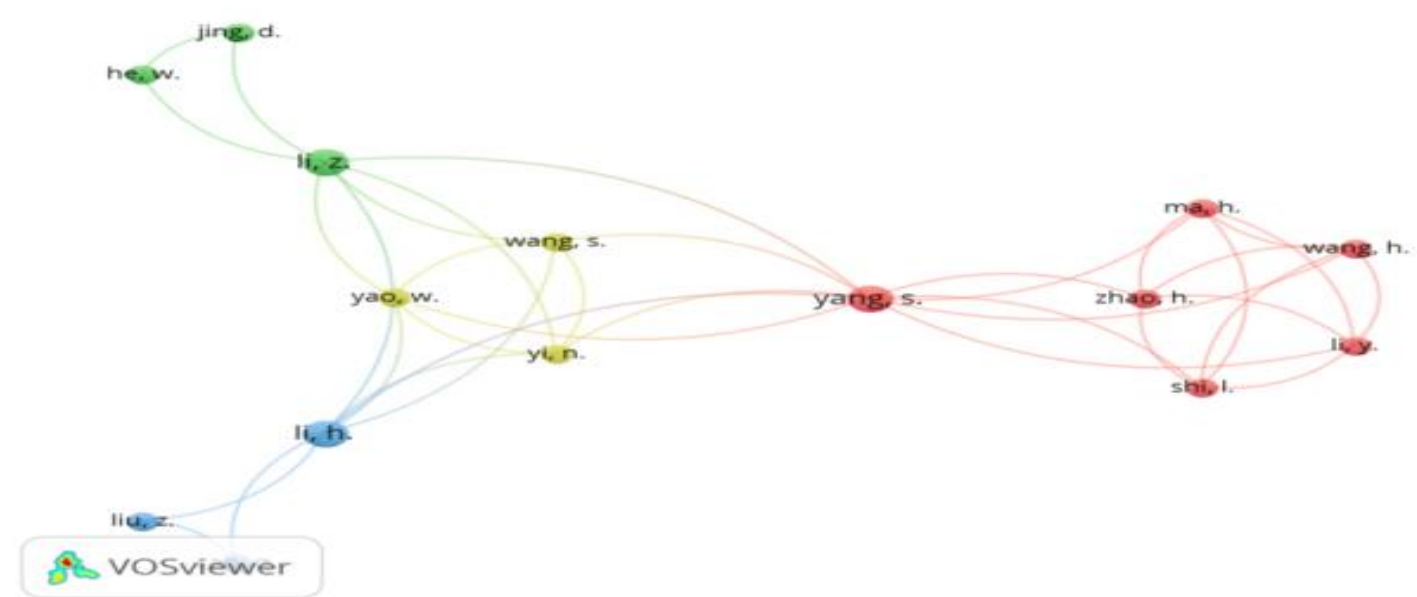

Gambar 4. Visualisasi Network author terkait dengan penelitian terdahulu

Identifikasi dalam Gambar 4 menunjukkan beberapa author yang telah melakukan penelitian terdahulu tentang topik bahasan yang relevan sesuai dengan riset peneliti yaitu tentang Development Planning dan Ecotourism. Dari hasil visualisasi network pada Gambar 4 tersebut dapat dilihat bahwa terdapat 4 klaster, yakni klaster 1 terdiri dari 6 items terletak pada bagian kanan berwarna merah, klaster 2 terdapat 3 items terletak pada bagian kiri atas berwarna hijau, klaster 3 terdapat 3 items terletak pada bagian kiri tengah berwarna kuning, dan klaster 4 terdapat 3 items terletak pada bagian kiri bawah berwarna biru. Untuk memperjelas visualisasi Gambar 4 tersebut, peneliti menyajikan visualisasi berbentuk tabel [Tabel 2]:
Tabel 2. Pengelompokan Author berdasarkan artikel tentang Development Planning dan Ecotourism

\begin{tabular}{clc}
\hline Klaster & \multicolumn{1}{c}{ Nama Author } & Total \\
\hline Klaster 1 & $\begin{array}{l}\text { Li, y; ma, h; shi,l; } \\
\text { wang, h; yang, s; } \\
\text { zhao,h }\end{array}$ & 6 \\
\hline
\end{tabular}

\begin{tabular}{lll}
\hline Klaster 2 & He, w; jing, d; li, z & 3 \\
\hline Klaster 3 & Cao, q; li, h; liu, z & 3 \\
\hline Klaster 4 & $\begin{array}{l}\text { Wang, s; yao, w; } \\
\text { yi,n }\end{array}$ & 3 \\
\hline
\end{tabular}

Setelah memetakan dan mengelompokkan visualisasi network ini, selanjutnya dilakukan pemetaan dan visualisasi berdasarkan density. Dari hasil visualisasi density [Gambar 5] dapat diidentifikasikan bahwa semakin padat warna sebuah author maka author tersebut lebih dominan. Pada Gambar 5 dapat dilihat bahwa author paling dominan adalah Yang, S, dimana dapat dilihat pada penggambaran visualisasi pada Gambar 5: 


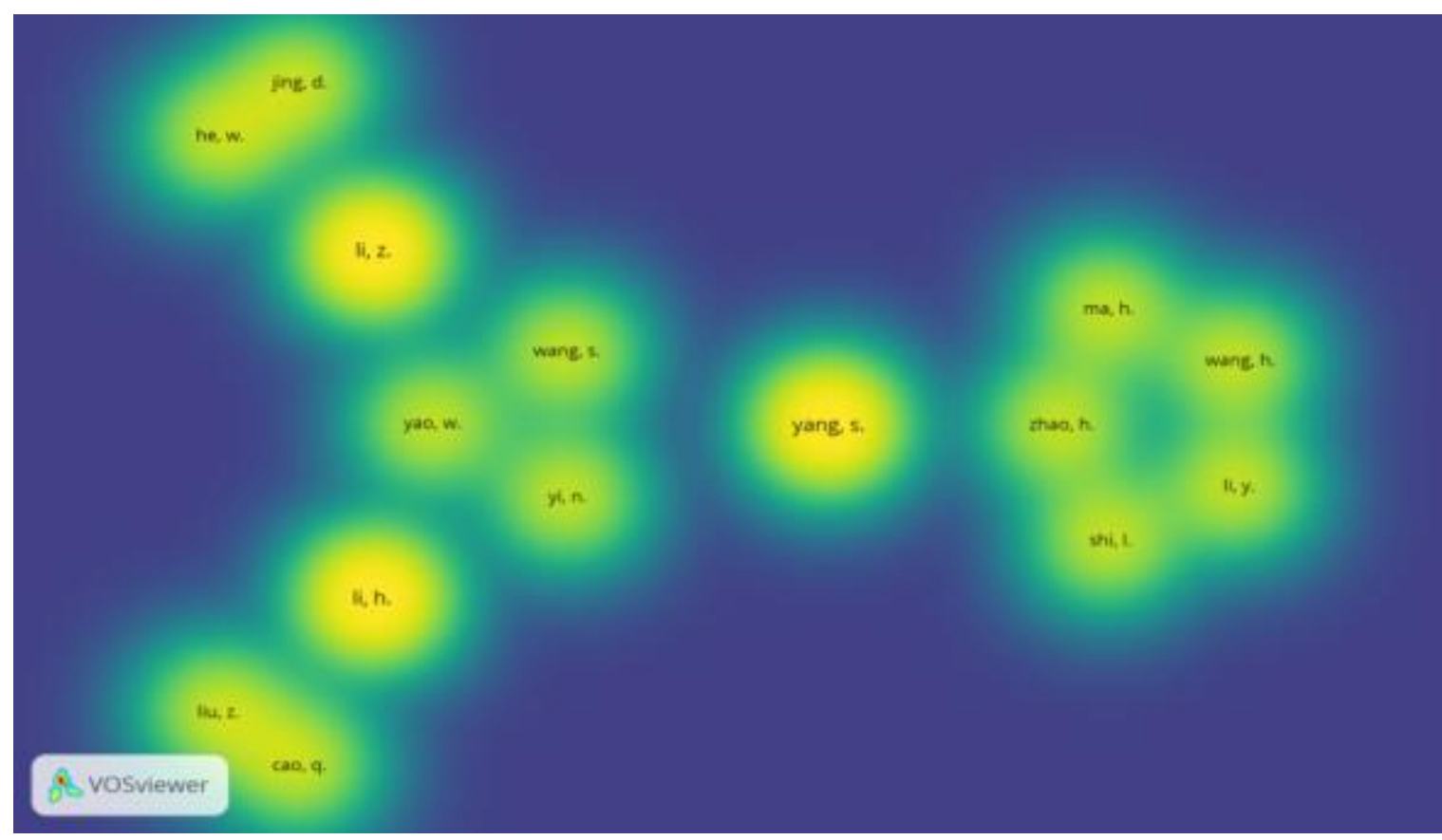

Gambar 5. Visualisasi density author berdasarkan penelitian terdahulu

Dari visualisasi density tersebut terlihat bahwa yang, s. lebih dominan bekerja sama dengan author-author yang lain. Selain yang, s. terdapat Li, h., dan Li,z juga mendominasi pada author. Dengan demikian tiga author tersebut juga bekerja sama dengan author lain yang tertera pada visualisasi gambar density tersebut.

Dominan penulis atau author pada klaster 1 adalah Yang, S dimana penelitian tersebut berjudul "Shangri-La county ecological land use planning based on landscape security pattern" mengemukakan bahwa dalam perencanaan ekologi lahan akan diusulkan tiga tingkat keamanan yaitu tinggi, sedang dan rendah, yang kemudian menjadi acuan untuk menyusun strategi keamanan ekologi di wilayah studi. Di wilayah studi, penggunaan lahan ekologis pada tingkat keamanan rendah, sedang dan tinggi masingmasing menempati $12.82 \%, 44.1 \%$ dan $80.3 \%$ dari total. Penggunaan lahan ekologis pada tingkat keamanan rendah yang mencadangkan garis dasar lahan minimum untuk menyelenggarakan fungsi jasa ekosistem alami (Li et al., 2011). Pada klaster 2 salah satunya dikemukakan oleh author $\mathrm{Li}, \mathrm{z}$ yang berjudul "Evaluation of health level of land-use ecosystem based on GIS grid model" menyatakan bahwa pengetatan batas atas kapasitas, mempertahankan garis bawah ekologis, memaksakan pemanfaatan lahan secara intensif, mengoptimalkan tata ruang "produksi, kehidupan dan ekologi", menyesuaikan struktur industri, dan mengembangkan ekowisata akan menjadi tindakan yang diperlukan untuk meningkatkan tingkat kesehatan ekologi penggunaan lahan dan membangun kota ekologi budaya lanskap yang terkenal (He et al., 2020).

Kemudian pada klaster 3 yang dikemukakan oleh author Li,h dengan judul "The construction of a marine tourism image based on grounded theory and the construction of sports thinking" menyatakan bahwa terdapat lima kategori utama yang digunakan dalam pengembangan ekowisata agar dapat digunakan sebagai alat keberhasilan, yakni pengembangan dan perencanaan, kognisi dasar, persepsi pengunjung, lingkungan, dan kondisi ekonomi. Strategi pembangunan daerah dengan potensi tinggi dan rendah juga dibahas dalam rangka meningkatkan daya saing pariwisata dan daya tarik spasial. Strategi pengembangan wilayah dengan potensi yang lebih tinggi dan lebih rendah juga menjadi perihal yang perlu dipertimbangkan dalam rangka meningkatkan daya saing pariwisata dan daya tarik spasial (Shijin et al., 2020). Pada klaster 4 tidak 
ditemukan author yang dominan dalam melakukan penelitian dan melakukan keterkaitan dengan peneliti lainnya.

\section{KESIMPULAN DAN REKOMENDASI}

Berdasarkan pembahasan yang telah dijelaskan oleh peneliti, kesimpulan dari adanya pembahasan tersebut adalah basis perencanaan pembangunan merujuk pada konteks tahapan yang harus dilalui untuk mencapai suatu tujuan. Adopsi dari adanya sebuah prosedur perencanaan pembangunan berbasis ekowisata dapat dilakukan oleh pihak pemerintah Indonesia. Selain itu, juga membahas terkait tren terhadap perkembangan perencanaan pembangunan berbasis ekowisata yang cakupannya sudah meluas di berbagai negara yang tersebar. Sedangkan, inovasi yang dapat dikembangkan di Indonesia sendiri adalah inovasi Community Based Ecotourism (CBE) atau ekowisata berbasis masyarakat, dengan demikian akan dapat menciptakan sebuah pariwisata dengan tetap melestarikan alam luar dan juga dapat menciptakan kawasan lindung pemanfaatan berkelanjutan (Santos et al., 2017).

Proyeksi perencanaan pembangunan dengan menciptakan inovasi berbasis ekowisata sudah banyak dilakukan di berbagai penjuru dunia. Dampak yang terjadi dari adanya pembangunan dengan keterkaitan sektor pariwisata membuat dampak yang positif bagi kehidupan masyarakat khususnya masyarakat perdesaan. Oleh karena itu, kajian ini perlu dilakukan untuk dapat merealisasikan pengembangan ekowisata dalam konteks pembangunan berkelanjutan yang dilakukan oleh pihak pemerintah dalam mewujudkan sebuah perubahan pada suatu wilayah. Selain itu, dari beberapa pemaparan hasil penelitian yang dilakukan di beberapa negara, juga dapat diadopsi pada lingkup wilayah Indonesia untuk menciptakan sebuah pembangunan suatu wilayah berbasis ekowisata yang disebut dengan Community Based Ecotourism atau CBE. Dilihat dari perspektif keberadaan sebuah kinerja pembangunan suatu wilayah melalui pariwisata atau CBE, kategori sumber daya juga memfasilitasi pembangunan berkelanjutan karena memungkinkan perencanaan jangka panjang. Selain itu, skala kecil mereka memungkinkan perusahaan pariwisata perdesaan untuk memanfaatkan sumber daya lokal dengan cara non-eksploitatif yang meminimalkan gangguan bagi pemangku kepentingan lainnya (Yachin \& Ioannides, 2020). Dengan demikian, konteks perencanaan pembangunan melalui ekowisata di Indonesia dapat menggunakan cara dan kinerja dari penelitian terdahulu yang dituangkan dalam sebuah tulisan.

Keterbatasan dalam penelitian ini yaitu peneliti hanya menyajikan korelasi tentang adanya pembangunan pada sektor pariwisata. Keterkaitan dari hubungan dua konsep kajian penelitian pada tahun terakhir yang baru tersebut masih terbatas, sehingga dari 311 jurnal secara keseluruhan pengkaji sulit untuk merelevansikan dengan tahun terakhir saat ini. Rekomendasi untuk penelitian selanjutnya adalah lebih banyak melakukan penelitian pada konteks tahun-tahun terbaru. Sehingga cakupan dari adanya penelitian ini lebih luas dan lebih relevan.

\section{UCAPAN TERIMA KASIH}

Ucapan terima kasih disampaikan penulis kepada Bapak Salahudin selaku dosen pembimbing yang telah berperan dalam penelitian tentang perencanaan pembangunan melalui ekowisata ini, sehingga penelitian dapat terlaksana dengan baik dan dapat dituangkan dalam bentuk tulisan. Dari dukungan pihak tersebut dapat menghasilkan naskah yang dapat dijadikan sebagai referensi oleh seluruh pihak.

\section{DAFTAR PUSTAKA}

Akbar, M. F., Suprapto, S., \& Surati, S. (2018). Partisipasi Masyarakat Dalam Perencanaan Pembangunan di Desa Jatimulya Kabupaten Boalemo. Publik: (Jurnal Ilmu Administrasi), $\quad 6(2), \quad 135$. https://doi.org/10.31314/pjia.6.2.135142.2017 
Arkema, K. K., Fisher, D. M., Wyatt, K., Wood, S. A., \& Payne, H. J. (2021). Advancing sustainable development and protected area management with social media- based tourism data. Sustainability (Switzerland), $13(5)$,

$1-19$. https://doi.org/10.3390/su13052427

Ayorekire, J., Obua, J., \& Manyara, G. (2019). Regional tourism in Inter-Governmental Authority on Development: A comparative policy and institutional best practice approach. International Journal of Tourism Policy, 9(1), 50-70. https://doi.org/10.1504/IJTP.2019.100079

Badan Pusat Statistik (BPS). (2018). Jumlah Devisa Sektor Pariwisata (Miliar US \$), 2016-2018. Retrieved from https://www.bps.go.id/indicator/16/1160/1/ju mlah-devisa-sektor-pariwisata.html

Baruah, P. (2020). Potential of urban wetlands for ecotourism development- a case of deepor beel, Guwahati. Nature Environment and Pollution Technology, 19(2), 611-625. https://doi.org/10.46488/NEPT.2020.V19I02. 016

Butler, M., Gering, E., \& Wilsey, D. (2017). Guiding local tourism entrepreneurs interested in ecotourism: A tool for extension facilitators. Journal of Extension, 55(5). Retrieved from https://www.scopus.com/inward/record.uri?ei $\mathrm{d}=2-\mathrm{s} 2.0$ 85031681120\&partnerID $=40 \& m d 5=9 d 1 d 39 f$ a408ff78dae44fe2d97c863bb

Ching, S.-L., Choong, Y.-O., Lau, L.-S., Seow, A.N., \& Choong, C.-K. (2020). Sustainable ecotourism development strategies through strengths, weaknesses, opportunities and threats analysis: The case of Cameron Highlands, Malaysia. Business Strategy and Development. https://doi.org/10.1002/bsd2.141

Choi, Y. E., Doh, M., Park, S., \& Chon, J. (2017). Transformation planning of ecotourism systems to invigorate responsible tourism. Sustainability (Switzerland), 9(12). https://doi.org/10.3390/su9122248

Choi, Y. E., Song, K., Kim, M., \& Lee, J. (2017). Transformation planning for resilientwildlife habitats in ecotourism systems. Sustainability (Switzerland),

9(4). https://doi.org/10.3390/su9040487

Datta, D., \& Banerji, S. (2015). Local tourism initiative in an eastern Himalayan village: Sustainable ecotourism or small-scale nature exploitation? Bulletin of Geography, 27(27), 33-49. https://doi.org/10.1515/bog-20150003
Duan, C., Shi, P., Song, M., Zhang, X., Zong, N., \& Zhou, C. (2019). Land use and land cover change in the Kailash Sacred Landscape of China. Sustainability (Switzerland), 11(6), 1788. https://doi.org/10.3390/su11061788

Đukić, V., \& Volić, I. (2017). The importance of documenting and including traditional wisdom in community-based ecotourism planning: A case study of the Nature Park Ponjavica in the village of Omoljica (Serbia). SAGE Open, 7(1). https://doi.org/10.1177/2158244016681048

Elbarmelgy, M. M., Gammaz, S. A., \& Hussien, M. S. (2019). Community-based ecotourism planning in Egypt, a case study: Evaluation of dahshur initiative. Journal of Engineering and Applied Science, 66(5), 539-561. Retrieved from https://www.scopus.com/inward/record.uri?ei $\mathrm{d}=2-\mathrm{s} 2.0$ -

$85073605476 \&$ partnerID $=40 \& \mathrm{md} 5=\mathrm{e} 0 \mathrm{ae} 72 \mathrm{e}$ 78ecc07bd94acb5079f87310a

Gohar, A., \& Mathias Kondolf, G. (2020). How eco is eco-tourism? A systematic assessment of resorts on the Red Sea, Egypt. Sustainability (Switzerland), 12(23), 1-20. https://doi.org/10.3390/su122310139

Guerrero, J. V. R., Gomes, A. A. T., de Lollo, J. A., \& Moschini, L. E. (2020). Mapping potential zones for ecotourism ecosystem services as a tool to promote landscape resilience and development in a Brazilian Municipality. Sustainability (Switzerland), 12(24), 1-21. https://doi.org/10.3390/su122410345

He, W., Li, Z., \& Jing, D. (2020). Evaluation of health level of land-use ecosystem based on GIS grid model. Nature Environment and Pollution Technology, 19(4), 1475-1482. https://doi.org/10.46488/NEPT.2020.v19i04. 013

Iliopoulou-Georgudaki, J., Kalogeras, A., Konstantinopoulos, P., \& Theodoropoulos, C. (2016). Sustainable tourism management and development of a Greek coastal municipality. International Journal of Sustainable Development and World Ecology, 23(2), 143-153.

https://doi.org/10.1080/13504509.2015.1102 780

Jiang, P., Shao, L., \& Baas, C. (2019). Interpretation of value advantage and sustainable tourism development for Railway Heritage in China based on the analytic hierarchy process. Sustainability (Switzerland), 11(22). https://doi.org/10.3390/su11226492 
Kuqi, B. (2018). Teoretical approach concerning the development of sustainable tourism as tourist destination in kosovo. Geojournal of Tourism and Geosites, 22(2), 489-496. https://doi.org/10.30892/gtg.22218-305

Lakner, Z., Kiss, A., Merlet, I., Oláh, J., Máté, D., Grabara, J., \& Popp, J. (2018). Building coalitions for a diversified and sustainable tourism: Two case studies from Hungary. Sustainability (Switzerland), 10(4). https://doi.org/10.3390/su10041090

Lee, J.-H., Kim, S.-H., \& Kwon, H.-S. (2017). Mapping interests by stakeholders' subjectivities toward ecotourism resources: The case of Seocheon-Gun, Korea. Sustainability (Switzerland), 9(1). https://doi.org/10.3390/su9010093

Li, H., Yi, N., Yao, W., Wang, S., Li, Z., \& Yang, S. (2011). Shangri-La county ecological land use planning based on landscape security pattern. Shengtai Xuebao/ Acta Ecologica Sinica, 31(20), 5928-5936. Retrieved from https://www.scopus.com/inward/record.uri?ei $\mathrm{d}=2$-s 2.0 -

80054912516\&partnerID $=40 \&$ md5=58f996a f6d3df0597ee2a4806418b54c

Mei, Y. (2016). Tourism evaluation model based on multi-objective fuzzy function. International Journal of Earth Sciences and Engineering, 9(3), 1102-1108. Retrieved from https://www.scopus.com/inward/record.uri?ei $\mathrm{d}=2$-s 2.0 -

84986206085\&partnerID $=40 \& m d 5=62 \mathrm{db} 674$ 7141a401d26e43041a6a91801

Mestanza-Ramón, C., Chica-Ruiz, J. A., Anfuso, G., Mooser, A., Botero, C. M., \& Pranzini, E. (2020). Tourism in continental ecuador and the galapagos islands: An integrated coastal zone management (ICZM) perspective. Water (Switzerland), https://doi.org/10.3390/w12061647

Mustanir, A., Kamarudding, S., Akhwan, A., Madaling, \& Mutmainna. (2018). Peranan Aparatur Pemerintahan Desa dan Partisipasi Masyarakat Dalam Musyawarah Perencanaan Pembangunan di Desa Tonrongnge Kecamatan Baranti Kabupaten Sidenreng Rappang. Jurnal Ilmiah Clean Government, 2(1), 67-84.

Noble, M. M., \& Fulton, C. J. (2020). Pathways to impact for aquatic conservation science via multi-modal communication and stakeholder engagement. Aquatic Conservation: Marine and Freshwater Ecosystems, 30(9), 17911797. https://doi.org/10.1002/aqc.3380
Nor, A. N. M., Isnorm, R. A., Abas, M. A., Malek, N. H. A., Hassin, N. H., Aziz, H. A., ... Rafaai, N. H. (2018). Landscape ecological assessment of potential ecotourism in Malaysia. International Journal of Civil Engineering and Technology, 9(10), 969979. Retrieved from https://www.scopus.com/inward/record.uri?ei $\mathrm{d}=2$-s 2.0 -

85056121579\&partnerID $=40 \&$ md5 $=\mathrm{c} 8 \mathrm{fbdfa} 7$ e7a5e2f539ced0567549f021

Pujar, S. C., \& Mishra, N. (2020). Ecotourism industry in India: a review of current practices and prospects. Anatolia. https://doi.org/10.1080/13032917.2020.1861 040

Pyke, J., Law, A., Jiang, M., \& de Lacy, T. (2018). Learning from the locals: the role of stakeholder engagement in building tourism and community resilience. Journal of Ecotourism, 17(3), 206-219. https://doi.org/10.1080/14724049.2018.1505 586

Rahardjanto, A., Husamah, H., Fatmawati, D., Miharja, F. J., \& Setyawan, D. (2019). The problematic implementation of communitybased ecotourism in Indonesia: A case study in ecotourism of Gili Labak-east java. African Journal of Hospitality, Tourism and Leisure, 8(SpecialEdition), 1-18. Retrieved from https://www.scopus.com/inward/record.uri?ei $\mathrm{d}=2$-s 2.0 -

$85083785498 \&$ partnerID $=40 \& \mathrm{md} 5=99 \mathrm{~cd} 746$ bfcf6f8cd092cf7628345484f

Salemi, M., Jozi, S. A., Malmasi, S., \& Rezaian, S. (2019). Conceptual framework for evaluation of ecotourism carrying capacity for sustainable development of Karkheh protected area, Iran. International Journal of Sustainable Development and World Ecology, 26(4), 354-366. https://doi.org/10.1080/13504509.2019.1570 379

Santos, L. C. M., Gasalla, M. A., Dahdouh-Guebas, F., \& Bitencourt, M. D. (2017). Socioecological assessment for environmental planning in coastal fishery areas: A case study in Brazilian mangroves. Ocean and Coastal Management, 138, 60-69. https://doi.org/10.1016/j.ocecoaman.2017.01. 009

Sarr, B., González-Hernández, M. M., Boza-Chirino, J., \& de León, J. (2020). Understanding communities' disaffection to participate in tourism in protected areas: A social representational approach. Sustainability (Switzerland), https://doi.org/10.3390/su12093677 
Shang, Y., Sun, Y., \& Xu, A. (2020). Rural ecotourism planning and design based on SWOT analysis. International Journal of Low-Carbon Technologies, 15(3), 368-372. https://doi.org/10.1093/IJLCT/CTAA003

Shijin, W., Jia, X., \& Lanyue, Z. (2020). China's glacier tourism: Potential evaluation and spatial planning. Journal of Destination Marketing and Management, 18. https://doi.org/10.1016/j.jdmm.2020.100506

Walter, P. (2020). Community-based ecotourism projects as living museums. Journal of Ecotourism, $\quad$ 19(3), 233-247. https://doi.org/10.1080/14724049.2019.1689 246

Wong, F. K. K., \& Fung, T. (2016). Ecotourism planning in Lantau Island using multiple criteria decision analysis with geographic information system. Environment and Planning B: Planning and Design, 43(4), 640-662. https://doi.org/10.1177/0265813515618583

Xiang, C., Xiao qin, J., \& Yin, L. (2020). Study on the rural ecotourism resource evaluation system. Environmental Technology and Innovation, 20. https://doi.org/10.1016/j.eti.2020.101131

Yachin, J. M., \& Ioannides, D. (2020). "Making do" in rural tourism: the resourcing behaviour of tourism micro-firms. Journal of Sustainable Tourism, 28(7), 1003-1021. https://doi.org/10.1080/09669582.2020.1715 993

Yekani Motlagh, E., Hajjarian, M., Hossein Zadeh, O., \& Alijanpour, A. (2020). The difference of expert opinion on the forest-based ecotourism development in developed countries and Iran. Land Use Policy, 94. https://doi.org/10.1016/j.landusepol.2020.104 549

Yuwono, E., Maulany, R. I., \& Barkey, R. A. (2021). SITE SUITABILITY EVALUATION FOR ECOTOURISM DEVELOPMENT: A CASE STUDY IN BULUE VILLAGE, SOPPENG DISTRICT, INDONESIA. Journal of Sustainability Science and Management, 16(1), 129-140. https://doi.org/10.46754/jssm.2021.01.012

Zhang, J., \& Sui, Y. (2020). Theoretical research on sustainable ecological environment based on the concept of green tourism consumption. International Journal of Environmental Technology and Management, 23(2-4), 8390.

https://doi.org/10.1504/IJETM.2020.112967
Zhou, P., Jiang, L., \& Xie, L. (2019). A study on the influence of ecotourism promotion method and brand attitude on consumers' willingness to buy. Ekoloji, 28(107), 1721-1727. Retrieved from https://www.scopus.com/inward/record.uri?ei $\mathrm{d}=2-\mathrm{s} 2.0-$

$85063913469 \&$ partnerID $=40 \&$ md5 $=2$ d39569 8aeb987b55ca161c1a87ae1f9 